\title{
KACPER PENCARSKI
}

ORCID 0000-0002-8333-6444

kacper.pencarski@apsl.edu.pl

(Akademia Pomorska w Słupsku, Archiwum Państwowe w Koszalinie)

\section{PREZENTACJA NAGRAŃ AUDIO I WIDEO W INTERNECIE PRZEZ ARCHIWA PAŃSTWOWE WOBEC WYBRANYCH PROBLEMÓW WYNIKAJĄCYCH Z POSZANOWANIA PRAW AUTORSKICH I PRAW POKREWNYCH. KILKA UWAG ŚRODOWISKA AKADEMICKIEGO}

\begin{abstract}
Słowa kluczowe: fonogramy, wideogramy, nagrania dźwiękowe, nagrania wizyjne, prawo autorskie, prawa majątkowe, prawa pokrewne, publikacja nagrań na stronach internetowych, wystawy wirtualne, strony internetowe, archiwa państwowe
\end{abstract}

\section{Streszczenie}

Przedmiotem niniejszej pracy jest próba zasygnalizowania najistotniejszych problemów wynikających z udostępniania szczególnej grupy materiałów archiwalnych, jakimi są nagrania dźwiękowe i wizyjne w kontekście potrzeb informacyjnych użytkowników, w tym na przykładzie uczniów i studentów. Autor wskazał na konkretne możliwości, jakie dają archiwom istniejące akty prawne, w tym ustawa o zasobie archiwalnym i archiwach (z późniejszymi zmianami) oraz ustawa o prawach autorskich i prawach pokrewnych. Zwrócił również uwagę na konieczność dopasowania istniejących rozwiązań związanych z udostępnianiem materiałów audiowizualnych do rzeczywistych potrzeb użytkowników z sugestią, by odejść od rozwiązań proponujących jedynie możliwość prezentacji dźwięku i obrazu jako sprawy samej w sobie (czyli wyłącznie ich opisów), lecz uatrakcyjnić istniejące witryny, a przede wszystkim wejść w interakcję z użytkownikami. Autor dokonał również zestawienia propozycji archiwów państwowych w kontekście usług związanych z reprografią materiałów dźwiękowych i wizyjnych, jak i wskazał na niezgodność ofert usług z deklaracją ich wykonania. Autor nieco uwagi poświęcił ponadto kwestii wykorzystania materiałów audiowizualnych przez archiwa państwowe, dochodząc do wniosku, że ten szczególny rodzaj materiałów archiwalnych jest promowany stosunkowo słabo, a także wskazał na najpilniejsze potrzeby w sprawie zmian prawnych, umożliwiających archiwom wykorzystanie dźwięku i obrazu do realizacji ich statutowych zadań, odnoszących się do udostępniania i promocji zasobu archiwalnego, jak i budowania pozytywnego wizerunku archiwów. 


\section{KACPER PENCARSKI}

ORCID 0000-0002-8333-6444

kacper.pencarski@apsl.edu.pl

(Pomeranian University in Słupsk, State Archives in Koszalin)

\section{ONLINE PRESENTATION OF AUDIO AND VIDEO RECORDINGS BY THE STATE ARCHIVES VERSUS THE ISSUES RELATED TO RESPECTING COPYRIGHT AND THE RELATED RIGHTS. SEVERAL COMMENTS OF THE ACADEMIA}

Keywords: phonograms, videograms, sound recordings, image recordings, copyright, property rights, related rights, online publication of recordings, virtual exhibitions, websites, national archives

\footnotetext{
Abstract

This paper focuses on signalling the most important problems related to sharing the special group of archive materials consisting of sound and image recordings in the context of the information needs of users, including school and university students. The author lists specific possibilities that archives have in the light of the existing legislation, including the Law on Archival Fonds and Archives (as amended) and the Copyright and Related Rights Law. He also draws attention to the need to adapt the existing solutions in the area of sharing audiovisual materials to the actual needs of users and suggests abandoning the solutions that come down to sound and image presentation (i.e. descriptions only) in favour of improving the appeal of the existing websites and, first and foremost, interacting with users. The author also presents the services offered by national archives in terms of reprography of sound and image materials, and he addresses the inconsistency between such offering and the declaration to provide them. The author addresses the use of audiovisual materials by national archives, arriving at a conclusion that this special type of archive materials receives relatively poor promotion. He also identifies the most urgent legislative changes required to allow archives to use sound and image in order to perform their statutory tasks of sharing and promoting archival fonds and building a positive image of archives.
} 
Różnorodność współczesnej dokumentacji, szczególnie tej, która została wytworzona w postaci nieaktowej i na innym, niż papierowy nośniku, jest i będzie cechą naszych czasów. W XX w. pozostałością po działalności człowieka stał się szczególny rodzaj dokumentacji $\mathrm{w}$ postaci materiałów audialnych, wizualnych i audiowizualnych. Nic więc dziwnego, że ten szczególny materiał historyczny wzbogacił (i skutecznie wzbogaca) nie tylko wiedzę o przeszłości, ale także uatrakcyjnia każdy przekaz i prezentację oraz inspiruje do dalszych badań i poszukiwań.

Korzystanie z dźwięku i obrazu, zwłaszcza tego o historycznym charakterze, jest szczególnie atrakcyjne dla odbiorcy, ale obarczone jest pewnym niebezpieczeństwem. Pamiętać należy, że pierwotnie każdy zapis dźwięku i obrazu był traktowany, szczególnie w końcu XIX i na początku XX w., jako nowoczesny środek, za pomocą którego utrwalono umyślnie wykreowane głosy i efekty dźwiękowe, a następnie muzyczne, podobnie jak i sekwencje obrazu. Procesami rejestracji zainteresowane były przede wszystkim firmy fonograficzne, korzystające $\mathrm{z}$ techniki zapisu dźwięku w celach komercyjnych; taka też idea przyświecała twórcom sposobów zapisu dźwięku. W XX w. utrwalony zapis dźwiękowy stanowił przedmiot zainteresowania użytkowników bibliotek, a następnie archiwów, stając się tym samym kolejnym źródłem informacyjnym, a w dalszej kolejności również materiałem o charakterze historycznym, stosunkowo łatwo budzącym emocje, jak i poddającym się krytyce ${ }^{1}$. Na świecie powstawały kolekcje dźwięków oraz filmów, w tym produkcji krótko- i pełnometrażowych, dając tym samym początek wielkim fonotekom i filmotekom na świecie, jak i niewielkim zbiorom, mającym nierzadko unikatowy charakter, zarówno pod względem wyjątkowości i niepowtarzalności utrwalonych treści, jak i pod względem sprofilowanych potrzeb użytkowników.

Stąd też, ze względu na wzrost zainteresowania i wykorzystania możliwości wynikających z rejestracji dźwięku i obrazu, skala, mnogość technicznych wariantów i zastosowanych rozwiązań technicznych i technologicznych, szczególnie w dziedzinie akustyki i optyki, doprowadziła do umożliwienia korzystania $\mathrm{z}$ tego rodzaju wynalazków nie tylko przez profesjonalne podmioty zajmujące się rejestracją, reprodukcją i rozpowszechnianiem nagrań dźwiękowych i filmowych, ale również przez osoby prywatne, szczególnie od lat 30 . XX w. Proces powstawania kolejnych audiogramów i wideogramów w tym znaczeniu szczególnie się nie zmienił; zmianom proporcji uległa liczba materiałów powstałych w wyniku działań osób prywatnych i innych podmiotów prawnych, które obecnie mają nieograniczone wręcz możliwości tworzenia i przechowywania (administrowania) powstałym materiałem audiowizualnym. Bez wątpienia jednakże

${ }^{1}$ G. Paszkowski, Nagrania dźwiękowe w archiwach, „Archeion” 1964, t. 41, s. 209 i n.; B. Kubiczek, Prace Międzynarodowego Zespotu Badawczego nad realizacja tematu. Opracowanie naukowych zasad oceny archiwalnej dokumentacji audiowizualnej (fotografii, nagrań i filmów), ibidem, 1984, t. 77, s. 257 i n.; J. Wojdon, Internetowe zasoby archiwów w nauczaniu historii - marzenia i rzeczywistość, ibidem, 2004, t. 107, s. 337. 
nośniki pozapapierowe, w tym fonogramy i wideogramy, wpłynęły na zmianę dotychczasowego postrzegania roli archiwów, bibliotek i muzeów, zaś badaczy zmusiły do korzystania z nowych form udostępniania wraz z użyciem niestosowanych dotąd narzędzi².

Nie będzie więc zaskoczeniem, że na skutek szerokich działań w tym zakresie, światowe dziedzictwo, w tym polskie, dysponuje ogromną ilością pojedynczych i zbiorowych nagrań dźwiękowych, wizyjnych i audiowizualnych. Zgodnie $\mathrm{z}$ danymi umieszczonymi w sprawozdaniu z działalności Naczelnego Dyrektora Archiwów Państwowych oraz archiwów państwowych w 2019 r., w krajowych archiwach znajdowało się według stanu na 31 grudnia 2019 r. 19085 filmów oraz 99670 dokumentów dźwiękowych ${ }^{3}$. W zbiorach tych znajdują się materiały o różnym stopniu zaawansowania technicznego, walorach poznawczych i estetycznych, przydatności informacyjnej, jak i o znacznym stopniu zróżnicowania pod względem możliwości ich wykorzystania. Uwarunkowań związanych z korzystaniem z materiałów audiowizualnych jest sporo, a należy do nich m.in. możliwość ich użycia bez ryzyka naruszenia praw autorskich, praw majątkowych i praw pokrewnych. I tu należy zastrzec - specyfika nagrań, uwzględniająca szereg innych aspektów skupionych nie tylko wokół twórcy (twórców), skutecznie komplikuje możliwość niekomercyjnego lub komercyjnego ${ }^{4}$ wykorzystania zawartych w dokumentacji audiowizualnej treści, a w wielu wypadkach czyni taki materiał „,martwym", nie w pełni przydatnym, a nawet wręcz uniemożliwia ich wykorzystanie.

$\mathrm{Z}$ jednej więc strony mamy do czynienia ze znacznym wzrostem zapotrzebowania udostępnienia materiału audiowizualnego nie tylko odbiorcom indywidualnym, ale także uczniom i studentom do rozmaitych celów poznawczych, zamykających się w grupie realizowanych przez szkoły i uczelnie zadań edukacyjnych, kształceniowych, czy zadań związanych z procesami uczenia się. $Z$ drugiej zaś strony obecne prawo skutecznie hamuje, czy wręcz uniemożliwia, pogłębioną edukację i kształcenie; uczniowie i studenci w celu głębszego zbadania tematu w oparciu o dźwięk i obraz korzystają z nie zawsze legalnych źródeł dystrybuujących interesujący ich materiał. Może to dziwić, jeśli uwzględnimy uprzywilejowanie archiwów państwowych w zakresie praw do postępowania z nagraniami, które są utworami ${ }^{5}$, jak i tymi, które w świetle ustawy o prawach autorskich nimi nie są. Znaczna część nagrań przechowywanych w archiwach

2 J. Łosowski, Archiwistyka jako dyscyplina pomocnicza historii, [w:] Nauki pomocnicze historii. Teoria, metody badań, dydaktyka, red. A. Jaworska i R. Jop, Warszawa 2013, s. 22.

3 Zestawienie sumaryczne KN-1 działalność archiwalna według stanu na dzień 31 grudnia 2019 r., https://www.archiwa.gov.pl/files/zestawienie sumaryczne_KN-1_2019.pdf [dostęp: 26.11.2020].

${ }^{4} \mathrm{O}$ komercyjnym wykorzystywaniu nagrań nie będzie w niniejszym opracowaniu mowy z uwagi na to, że w odniesieniu do archiwów państwowych trudno mówić o komercyjności przedsięwzięć, w których wykorzystuje się materiał archiwalny.

5 Ze względu na szerokie znaczenie pojęcia ,utwór” oraz warunki, w jakich można mówić o utworze, jak i o prawnych cechach i usytuowaniu utworu, autor zrezygnował z przytaczania definicji i prawnego usytuowania ,utworu”. Definiuje go zarówno Ustawa z dnia 4 lutego 1994 r. o prawie 
państwowych nie jest przecież przedmiotem prawa autorskiego (choć może być przedmiotem innych praw). Należą do nich te materiały, które stanowią akty normatywne lub ich urzędowe projekty czy dokumenty urzędowe (w myśl art. 4 ustawy o prawach autorskich i prawach pokrewnych) ${ }^{6}$.

Pozorne jednakże prawne uprzywilejowanie archiwów państwowych nie rozwiązuje problemu wynikającego z braku sposobności pełnego wykorzystania materiału dźwiękowego lub wizyjnego, w tym możliwości jego udostępniania w zakresie prowadzonych statutowych działań państwowej sieci archiwalnej. Mowa jest o tym wprawdzie w ustawie o narodowym zasobie archiwalnym $\mathrm{i}$ archiwach z 14 lipca 1983 r., gdy przywołuje się przedmiot zainteresowań państwowej sieci archiwalnej, którym są ,,wszelkiego rodzaju [...] filmy [...], nagrania dźwiękowe i wideofonowe" ustawodawca przypisał szczególną rolę - materiały te „służą nauce, kulturze, gospodarce narodowej oraz potrzebom obywateli” (art. 2), a więc wyznaczył im określoną rolę m.in. w edukacji i kształceniu.

Do państwowego zasobu archiwalnego w ostatnich latach weszły również materiały niepaństwowe. Archiwa państwowe mogą przejąć archiwalny materiał audiowizualny, który dotąd stanowił własność zarówno niepaństwowych jednostek organizacyjnych, jak i osób prywatnych (art. 11). Ustawa wymienia podmioty, które tworzą materiał archiwalny w ramach państwowego zasobu archiwalnego, w tym dopuszcza włączenie do tej grupy materiałów audiowizualnych stanowiących przed przejęciem ich do archiwum państwowego własność prywatną (art. 15), przy zastrzeżeniu, że materiały te są świadectwem działalności ,rodzin i rodów, które wywierały historyczny wpływ na sprawy państwowe, stosunki polityczne, gospodarcze i społeczne" (art. 15 ust. 1 pkt 5). Dokumentacja audiowizualna umożliwia dodatkowo zapoznanie się z tymi indywidualnymi cechami i postawami osób, które nie dadzą się uchwycić podczas analizy źródeł pisanych, co nie tylko wzbogaca wiedzę biograficzną, ale czyni przekaz materiału bardziej atrakcyjnym.

Udostępnianie materiałów archiwalnych, w tym dokumentacji audiowizualnej, oparto na kluczowych przepisach prawnych. Nadrzędnym z nich jest Konstytucja Rzeczypospolitej Polskiej z 1997 r. ${ }^{8}$, która gwarantuje każdemu obywatelowi pra-

autorskim i prawach pokrewnych (t.j.: Dz.U. 2019, poz. 1231; Dz.U. 2020, poz. 288), jak i bogata na ten temat literatura.

${ }^{6}$ Ustawa z dnia 4 lutego 1994 r. o prawie autorskim..., art. 4; K. Kurosz, Artystyczne wykonanie utworu. Prawa osobiste i majątkowe aktorów, muzyków i innych wykonawców, Warszawa 2014, s. 111-116; C. Błaszczyk, Propertarianistyczne teorie prawa autorskiego, Warszawa 2018, s. 34-55; Prawo autorskie i prasowe, 23. wydanie, Stan prawny: 14 września 2018 r., opr. A. Flisek, Warszawa 2018, s. 3.

7 Ustawa z dnia 14 lipca 1983 r. o narodowym zasobie archiwalnym i archiwach (t.j.: Dz.U. 2019, poz. 553, 730, 2020). O dokumentacji audiowizualnej jako dokumentacji specjalnej szerzej zob.: M. Jabłońska, Dokumentacja specjalna w archiwach. Opis tradycyjny i komputerowy, Toruń 2011, s. 69-75.

${ }^{8}$ Dz.U. 1997, nr 78, poz. 483. 
wo dostępu do dotyczących go urzędowych informacji i zbiorów danych (art. 51, ust. 1, pkt 3), a także zapewnia każdemu obywatelowi wolność twórczości artystycznej, badań naukowych i ogłaszania ich wyników, a także wolność korzystania z dóbr kultury (art. 73). Precyzyjniejsze w tym zakresie stają się sformułowania zawarte w ustawie o narodowym zasobie archiwalnym i archiwach, która gwarantuje prawo każdej osoby do dostępu do materiałów archiwalnych (art. 16a, ust. 1). Ustawodawca dodatkowo zastrzegł, że przedmiotem udostępniania może być nie tylko materiał archiwalny z państwowego zasobu archiwalnego, ale również z niepaństwowego, o ile nie wyłączono możliwości jego udostępnienia (art. 16a, ust. 3). Perspektywy związane z zaspokajaniem potrzeb informacyjnych zbiorowości, jak i osób indywidualnych, są nieograniczone i skupiają się przede wszystkim wokół celów poznawczych (w tym na użytek badań naukowych), bądź celu zaspokojenia osobistych potrzeb informacyjnych (art. 16a, ust. 4, pkt 1). Korzystający ma zapewnioną możliwość osobistego zapoznania się z treścią dokumentacji audiowizualnej oraz ma prawo wykonać odzwierciedlenie tej dokumentacji (art. 16d, ust. 1, pkt 1). $\mathrm{Z}$ drugiej zaś strony istnieją ograniczenia wynikające $\mathrm{z}$ realizacji przepisów zawartych $\mathrm{w}$ ustawach o ochronie informacji niejawnych, tajemnic ustawowo chronionych oraz wynikające $\mathrm{z}$ ochrony danych osobowych i dóbr osobistych. Ustawa jednakże nie narzuca obowiązku prowadzenia jakichkolwiek działań, które prowadziłyby do zbiorczego prezentowania zawartych w materiale archiwalnym danych (zamiast prezentowania ich w sposób jednostkowy), jak i do anonimizacji oraz częściowego wyłączenia treści zawartych w archiwaliach; nie narzuca również takiego obowiązku na te podmioty, które dysponują materiałem archiwalnym i udostępniają go, a nie zaliczają się do archiwów państwowych (art. 22c, ust, 1; ust. 2, pkt 1-3).

W tym miejscu należy zastrzec, że mnogość zadań archiwów i postępująca już od kilku lat cyfryzacja materiałów audiowizualnych, a nawet istnienie archiwaliów wyłącznie w postaci elektronicznej, wymusiły konieczność przeprofilowania działań archiwów (i w pewnym stopniu również ich użytkowników), wymuszając użycie cyfrowej sekwencji danych jako źródła informacji. Wszystkie zadania realizowane w tym zakresie wpisują się we współczesny model społeczeństwa informatycznego oraz podlegają (i będą podlegać) identycznym procesom, co każda dziedzina życia politycznego, społecznego i gospodarczego, jeśli podstawowym jej narzędziem jest informacja ${ }^{9}$. Kierunek i tempo cyfryzacji i informatyzacji w Polsce z pewnością będą świadczyć o stopniu modernizacji państwa. Zarówno klient, jak i archiwista wkraczają tym samym w delikatną sferę poszanowania praw, których, w przypadku tradycyjnej postaci materiałów archiwalnych, uwzględnienie nie zawsze było konieczne. Sprawa ta komplikuje się jeszcze bardziej w razie umieszczenia kopii materiałów audiowizualnych $\mathrm{w}$ internecie. Mamy więc do czynienia z wykluczającymi się z definicji zja-

\footnotetext{
${ }^{9}$ M. Kowalczyk, Cyfrowe państwo. Uwarunkowania i perspektywy, Warszawa 2019, s. 79-82.
} 
wiskami $-\mathrm{z}$ jednej strony otwartości materiałów audiowizualnych na potrzeby użytkowników bez względu na sposób prezentacji (udostępniania) nagrań, z drugiej zaś ograniczenia tej otwartości w zakresie rozpowszechniania (publikacji) tych samych materiałów w internecie ${ }^{10}$.

Szczególny tryb udostępnienia materiałów archiwalnych, w tym dokumentacji audiowizualnej, określony został w Rozporządzeniu Rady Ministrów z dnia 22 czerwca 2011 r. w sprawie sposobu i trybu udostępniania materiałów archiwalnych znajdujących się $\mathrm{w}$ archiwach wyodrębnionych ${ }^{11}$. Nie wnikając w różnice odnoszące się do technicznego procesu przygotowania udostępniania materiałów, zastrzec należy, że i w tym przypadku obywatel ma prawo do zapoznania się z treścią archiwaliów w sposób bezpośredni lub pośredni (art. 2, ust. 1). Umożliwia się dostęp do dokumentacji audiowizualnej na zasadach identycznych jak w przypadku pozostałych grup materiałów archiwalnych w celu sporządzenia materiałów prasowych, produkcji radiowych i telewizyjnych, filmów dokumentalnych i dla celów własnych osób fizycznych, o ile nie naruszają istotnych interesów Skarbu Państwa (art. 6, ust. 1, pkt 1-4).

Obok formalnej podstawy udostępniania materiałów audiowizualnych jako rodzaju materiałów archiwalnych, istnieje również konieczność zaspokojenia informacyjnych potrzeb obywateli, idąca w parze ze zmianą wizerunku archiwów jako takich. $Z$ jednej strony mamy do czynienia $\mathrm{z}$ niezwykle interesującym materiałem archiwalnym, działającym na zmysły słuchu lub wzroku (bądź słuchu i wzroku), z drugiej zaś ze znaczną blokadą wynikającą z konieczności poszanowania praw autorskich, a szczególnie majątkowych. Tego rodzaju dokumentacja, przy właściwej promocji archiwów państwowych i ich zasobów, może skutecznie zwiększyć pozycję społeczną archiwów, przyczynić się do zerwania z traktowaniem ich jako stereotypowo niedostępnej zwykłemu obywatelowi skarbnicy informacji, a przede wszystkim przyczynić się do włączenia materiałów audiowizualnych do narzędzi pracy i źródeł pozyskania informacji przez każdego zainteresowanego. Nagraniom towarzyszy większy niż w przypadku dokumentacji aktowej (papierowej) potencjał przemawiający za tym, by uczynić z nich źródło inspiracji dla każdego - naukowca, artysty, dziennikarza, regionalisty itp., a nie wyznaczać materiałom audiowizualnym funkcji wyłącznie prezencyjnej czy ciekawostki w zasobie (zbiorze) ${ }^{12}$.

\footnotetext{
${ }^{10}$ A. Niewęgłowski, Obrót materiałami archiwalnymi - zagadnienia wybrane, „Archeion” 2014, t. 115, s. 50-51; M. Konstankiewicz, Kompetencje w zakresie prawnych aspektów ochrony własności intelektualnej i dóbr osobistych w cyfrowym warsztacie archiwisty, [w:] Archiwistyka cyfrowa i nauki pomocnicze historii w edukacji archiwalnej. Problemy dydaktyki archiwistyki, Warszawa 2016, s. 35.

${ }^{11}$ Rozporządzenie Rady Ministrów z dnia 22 czerwca 2011 r. w sprawie sposobu i trybu udostępniania materiałów archiwalnych znajdujących się w archiwach wyodrębnionych (Dz.U. 2011, nr 196, poz. 1161).

${ }^{12}$ Szerzej na ten temat, jednakże w kontekście zarządzania archiwami, zob.: M. Jabłońska, Nowe wyzwania archiwów. Komunikacja społeczna i public relations, Toruń 2016, s. 39-40.
} 
Archiwa w Polsce niedostatecznie korzystają z możliwości, jakie dają im tego rodzaju akty prawne. W ustawie o prawach autorskich wielokrotnie jest mowa o konsekwencjach o charakterze sankcji w przypadku wykorzystania cudzego utworu, o ile wykorzystanie to wiąże się z uzyskaniem korzyści majątkowej. Charakter działań archiwów, szczególnie w zakresie udostępnienia materiałów audiowizualnych przez Internet, obecnie nie wpisuje się w zakres wykorzystania utworu w takim charakterze. Archiwa, obok bibliotek i muzeów, mają możliwość zwielokrotnienia utworów ze swoich zbiorów w ramach np. prowadzenia prac konserwatorskich oraz, w sposób ograniczony, przez końcówkę systemu informatycznego, udostępniania tych zbiorów (art. 28, ust. 1, pkt 1-3) ${ }^{13}$. Ustawa dopuszcza również możliwość przytoczenia części rozpowszechnionych już utworów na prawach cytatu ${ }^{14}$ (art. 29), a także umożliwia zwielokrotnianie utworów, które są niedostępne w obrocie handlowym i ich udostępnianie w taki sposób, by każdy miał do nich dostęp w czasie i miejscu przez siebie wybranym (art. 35, ust. 2). Dodatkowe uprawnienia nadała archiwom dyrektywa 2001/29/ WE Parlamentu Europejskiego i Rady, zgodnie z treścią której istnieje możliwość wyłączenia $\mathrm{w}$ prawie krajowym niektórych przepisów prawa autorskiego w celu udostępniania zbiorów przy użyciu terminali w pomieszczeniach ${ }^{15}$. Dodatkowym zabezpieczeniem w przypadku utworów może być umowa przenosząca prawa autorskie oraz umowa licencyjna ze wskazaniem skutków prawnych i pól eksploatacji oraz (ewentualnie) z określeniem granic tych pól ${ }^{16}$.

Nic więc dziwnego, że takie rozbieżności formalne, a w ich konsekwencji zaniechanie promocji i prezentacji materiałów audiowizualnych, prowadzą do zaskakujących efektów. Sposób przedstawienia materiałów dźwiękowych i wideofonowych, jaki ma miejsce w przypadku ich udostępnienia na przykład poprzez stronę Internetową ,audiovis.nac.gov.pl" ${ }^{17}$ nie może spełniać kryterium intuicyjnego wyszukiwania informacji, a przede wszystkim narzędzia satysfakcjonującego użytkownika (klienta), gdyż samo otwarcie strony głównej witryny daje użytkownikowi wrażenie chaosu i przypadkowego doboru prezentowanego tam materiału. Praktycznie trudno określić czy witryna ta jest katalogiem, wyszukiwarką, czy też prezencyjnym repozytorium nagrań (i to tylko wobec tych, które

${ }^{13}$ B. Howorka, Prawo autorskie w pracy bibliotekarza, Warszawa 2012, s. 155-170.

14 Szerzej o zastosowaniu cytatu, zob. w: R. Wojciechowski, Prawo autorskie, [w:] Prawo autorskie i własności przemysłowej. Wybrane zagadnienia, red. R. Wojciechowski, Siedlce 2014, s. 109111.

15 Dyrektywa 2001/29/WE Parlamentu Europejskiego i Rady z dnia 22 maja 2001 r. w sprawie harmonizacji niektórych aspektów praw autorskich i pokrewnych w społeczeństwie informacyjnym (Dz. Urz. WE L 167/10); B. Howorka, op.cit., s. 170.

${ }_{16}$ T. Targosz, K. Włodarska-Dziurzyńska, Umowy przenoszące autorskie prawa majątkowe, Warszawa 2010, s. 82, 165-167, 182-183, 190-193; R. Golat, Prawo autorskie i prawa pokrewne, Skrypty Becka, Warszawa 2016, s. 88.

17 Zbiory Narodowego Archiwum Cyfrowego on-line, https://audiovis.nac.gov.pl/ [dostęp: 26.06.2020]. 
mogą być w takiej formie publikowane w Internecie). Może jednak witryna pełni funkcję wirtualnej wystawy? Trudno na te pytania jednoznacznie odpowiedzieć, gdyż brakuje na niej jakiejkolwiek informacji co do jej funkcji, strategii tego, co jest i co będzie na niej udostępnione oraz kiedy, gdyby pominąć dane dotyczące łącznej liczby fotografii i nagrań umieszczonych na stronie. Według stanu na 26 czerwca 2020 r., zgodnie z informacją zawartą na stronie, dostępnych na niej było 219655 fotografii i 14998 nagrań i to praktycznie stanowi jedyną informację na temat tego, kto i w jakim celu oraz w jakim układzie (w oparciu o jaki klucz) prezentuje zawarty tu materiał. Sposób wyszukiwania informacji jest bliższy obsłudze katalogu zbioru nagrań niż prezentacji. Interesująca zawartość witryny przegrywa niestety z jej topornością, zaś korzystający z niej, po dotarciu do informacji, opuszcza ją niestety bez satysfakcji, gdyż najczęściej natrafia na dane o treści „nagranie dostępne tylko w Biurze Obsługi Klienta”, które - co wydaje się nieco egzotyczne - można „dodać do ulubionych” [sic!]. Użytkownik może również czuć dyskomfort w kwestii wyszukiwania informacji i jej samodzielnego grupowania; przykładowo, próba wyszukania nagrań z pominięciem dodatkowych atrybutów z 1939 r. w witrynie daje rezultat wyszukania 147 materiałów dźwiękowych o krajowej i zagranicznej proweniencji (i to najczęściej niemieckich), z których nie można odsłuchać żadnego (gdyż ich tam nie dołączono), ale także i te nieistniejące nagrania można „,dodać do ulubionych”. Korzystający z witryny już nie dowie się niczego więcej: dlaczego przeważają tu nagrania niemieckie, dlaczego znajduje się tu mało nagrań polskich, a przecież na tego rodzaju, wręcz intuicyjnie, powstałe pytania można byłoby odpowiedzieć użytkownikom, gdyby sposób prezentacji nagrań uwzględniał nawiązanie swoistej relacji pomiędzy korzystającymi z zasobów tej konkretnej strony z jej twórcami. Nie pomniejsza to oczywiście w żadnym wypadku starań i działań przede wszystkim tych, którzy założyli tę witrynę, ale można odnieść wrażenie, że nie uwzględniono $\mathrm{w}$ procesie powstania strony interakcji z użytkownikiem, dając mu do dyspozycji to, ,co jest w inwentarzu”. Wprawdzie Narodowe Archiwum Cyfrowe, zdaniem Joanny Chojeckiej, jest zaliczane do grupy liderów wśród pozostałych archiwów państwowych w zakresie udostępniania materiałów audiowizualnych ${ }^{18}$, ale $\mathrm{z}$ pewnością brakuje tutaj możliwości szerszego włączenia obecnych i potencjalnych użytkowników w całościowy proces „ożywienia” historycznych materiałów dźwiękowych i wizualnych (w każdym razie proces ten postępuje wolniej niż przewidywano to w 2011 r. ${ }^{19}$ ), budowy szczególnej interakcji z odbiorcą ich treści, a także większego niż dotąd wzbudzania inspiracji historycznym dźwiękiem i obrazem, oczywiście z poszanowaniem prawa autor-

18 J. Chojecka, Archiwa otwarte. O obecności archiwów państwowych w przestrzeni publicznej w kontekście założeń, realizacji i efektów strategii archiwów państwowych na lata 2010-2020, „Archeion" 2019, t. 120, s. 132.

${ }_{19}$ W. Woźniak, Misja Narodowego Archiwum Cyfrowego - spojrzenie w przyszłość, „Archeion” 2012, t. 113 , s. 87 i n. 
skiego i praw pokrewnych. Zjawisko to zresztą ma miejsce, jednakże poza siecią archiwów państwowych - i trzeba to przyznać - nie w taki sposób, jaki mógłby przekuć się w sukces całej państwowej sieci archiwalnej. Nagrania, nierzadko pochodzące $\mathrm{z}$ archiwów państwowych, a nieudostępniane na stronie takiej jak „audiovis.nac.gov.pl”, stanowią podstawę do tworzenia nowych treści, w których inspiracją jest szeroko rozumiana historia, bądź tylko określony kontekst historyczny wydarzenia czy związanej z nim osoby. Działania takie prowadzą zarówno osoby zajmujące się zawodowo historią i naukami pokrewnymi, jak i osoby traktujące problematykę swoich zainteresowań amatorsko.

Powstaje więc zasadnicze pytanie - po co tworzyć tego rodzaju strony internetowe, jeśli nie spełniają one swoich funkcji? Jakie zresztą te funkcje są - czy są może wyłącznie wyrazem nieco ambicjonalnych zadań instytucji, gdzie, pod zachowawczym pozorem poszanowania praw autorskich i praw pokrewnych, użytkownik dysponuje mocno ograniczoną treściowo bazą danych, w której nagrania zaprezentowane będą tylko wówczas, gdy upłyną terminy uniemożliwiające przedstawienie materiałów dźwiękowych? I czy wszystko to będzie w przyszłości odbywać się na istniejącej witrynie internetowej? Czy tak też ma wyglądać promocja pozaaktowego zasobu archiwalnego?

Z pewnością witryna, jak i strony internetowe tych archiwów państwowych, które mają materiał audiowizualny i możliwości udostępnienia zbiorów przez Internet, mogłyby zostać uatrakcyjnione na przykład poprzez wprowadzenie rzeczowego i chronologicznego podziału prezentowanych nagrań (analogicznie można ten sposób zastosować do zamieszczonych tu fotografii, jednakże kwestię tę pominę z uwagi na odrębność zagadnienia), co już samo w sobie wzbudza większe zainteresowanie. Każde z przedstawionych nagrań nie musi być dostępne w całości, a może być poprzedzone krótkim słowem wstępnym i udostępnione na prawach cytatu w jednym dokumencie dźwiękowym. Takie rozwiązanie sytuacji mogłoby stanowić swoiste „ożywienie” prezentowanych treści nagrań, omawiać kontekst ich powstania, a nawet, w przypadku nagrań złych technicznie, krótko omawiać przyczyny złego stanu, co gwarantuje zwiększenie zainteresowania konkretnym dźwiękiem czy obrazem. Nie trzeba nadmieniać, że tego rodzaju zabiegi można oprzeć o prawo cytatu.

Ponadto jeszcze nie w pełni wykorzystuje się w Polsce techniczne i teleinformatyczne możliwości zabezpieczeń o charakterze prewencyjnym co do zapobiegania naruszeń prawa $\mathrm{w}$ przypadku udostępniania przez Internet. Chodzi tu szczególnie o wykluczenie ryzyka zapisu nagrania audio i (lub) wideo materiałów umieszczonych w sieci, autoryzację dostępu i monitoring zachowań niepożądanych (art. 6, ust. 1, pkt 8-11). Tego rodzaju zabezpieczenia, jak i sposób prezentacji własnych materiałów, są już stosowane w Polsce (np. przez Telewizję Polską czy Polskie Radio).

W wypadku prawa majątkowego, zapisy ustawy o narodowym zasobie archiwalnym i archiwach wykluczyły możliwość wykonania autorskich praw mająt- 
kowych przez archiwa państwowe wobec podmiotów, którym materiał archiwalny udostępniono, pod warunkiem, że prawa te przysługują Skarbowi Państwa (art. 16 c ust. 1 pkt 2). Interesujące jest to, że prawo własności, przysługujące osobom, które wytwarzały bądź przechowywały nagrania $\mathrm{z}$ niepaństwowego nieewidencjonowanego zasobu archiwalnego, spoczywa wyłącznie na osobie fizycznej i może być ograniczone tylko w zakresie czasowego wywozu za granicę i pod warunkiem zwrotu (art. 46, art. 47 ust. 1). Sposób przekazania praw własności archiwum państwowemu określają umowy kupna-sprzedaży, darowizny czy spadku. Umowy też określają, przy uwzględnieniu zapisów dotyczących archiwów, warunki wykonania praw majątkowych i pokrewnych. W większym więc stopniu należałoby uwzględnić możliwość prezentacji materiałów archiwalnych w Internecie, zastrzegając takie prawo przez stronę, jaką w umowie jest archiwum.

Kolejną kwestią są koszty reprodukcji. To zagadnienie w archiwach można rozpatrzeć zarówno w kategoriach zwiększenia dostępności do ich zasobów, jak i jako barierę. Użytkownik ma możliwość sporządzenia kopii nagrania, ale w oparciu o oryginalny nośnik. Nie byłoby w tym nic szczególnego, gdyby nie to, że tylko kilka z archiwów dysponuje odpowiednim zapleczem technicznym. Jeszcze gorzej przedstawia się możliwość dokonania kopii materiałów filmowych. Przegląd usług archiwalnych, po ujednoliceniu stawek w sieci archiwalnej, pozwala wysunąć fałszywy wniosek, że w żadnym z archiwów nie prowadzi się usług związanych z przegrywaniem obrazu z dokumentacji audiowizualnej. Spośród archiwów i fonotek, które wykonują reprodukcje materiałów audiowizualnych, jeszcze do połowy 2020 r. istniały znaczne rozbieżności co do kosztów ich wykonania, ale niektóre z placówek taką możliwość uwzględniały (przynajmniej teoretycznie). W Rozporządzeniu Rady Ministrów z dnia 22 czerwca $2011 \mathrm{r}$. w sprawie sposobu i trybu udostępniania materiałów archiwalnych znajdujących się w archiwach wyodrębnionych wymieniono kwotę 5 zł za wykonanie 1 minuty nagrania analogowego z montażem (na nośniku zamawiającego) i 2,5 zł za wykonanie 1 minuty nagrania cyfrowego z montażem (na nośniku zamawiającego ${ }^{20}$; w praktyce w różnych archiwach koszty te kształtowały się rozmaicie. Po ujednoliceniu stawek, co nastąpiło w kwietniu 2020 r., za wykonanie usługi związanej ze skopiowaniem dźwięku w archiwach państwowych, co do zasady przyjęto, że usługa będzie szacowana na kwotę 5,00 za każdą rozpoczętą minutę dźwięku podczas pracy z jego oryginalnym nośnikiem. W cennikach zastrzeżono, że archiwa wykonają kopię nagrania tylko jeśli będą miały techniczną możliwość, a że z reguły samodzielnie jej nie mają, toteż zawarcie informacji o możliwości dokonania przekopiowania nagrania jest zbędna.

${ }^{20}$ Załącznik do rozporządzenia Rady Ministrów z dnia 22 czerwca 2011 r. w sprawie sposobu i trybu udostępniania materiałów archiwalnych znajdujących się w archiwach wyodrębnionych (Dz.U. 2011, nr 196, poz. 1161). 


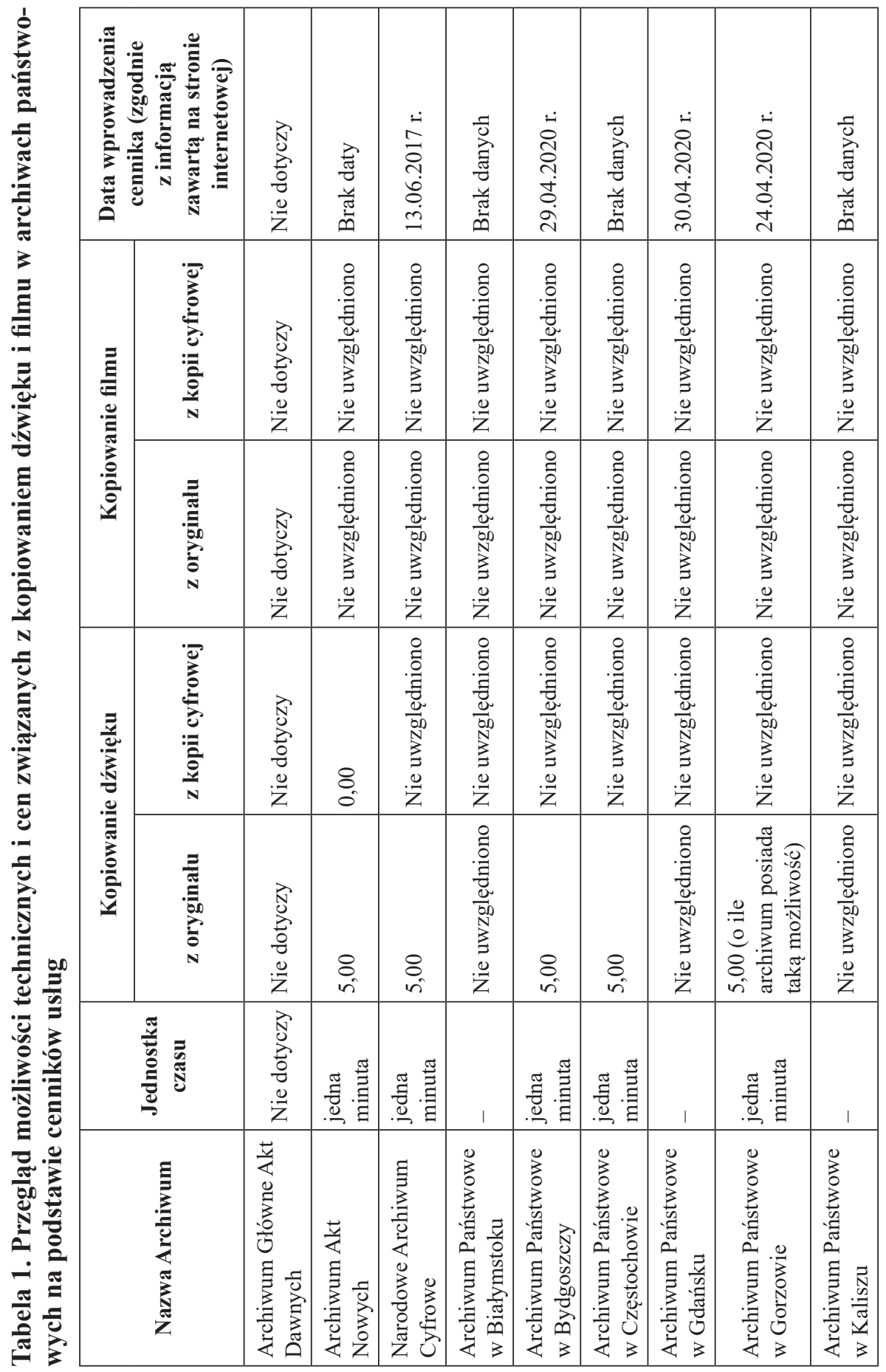




\begin{tabular}{|c|c|c|c|c|c|c|c|c|c|c|c|}
\hline \multicolumn{2}{|c|}{ 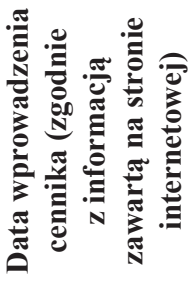 } & 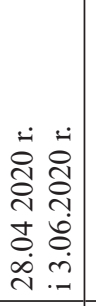 & 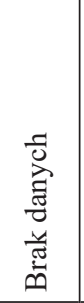 & 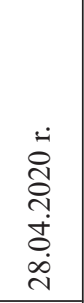 & 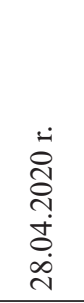 & 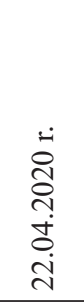 & 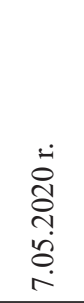 & $\begin{array}{l}\dot{-1} \\
\text { Oे } \\
\text { ते } \\
\dot{0} \\
\dot{0} \\
\text { i }\end{array}$ & 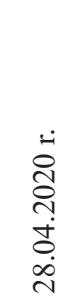 & $\begin{array}{l}\dot{-1} \\
\stackrel{0}{0} \\
\text { } \\
\dot{0} \\
\stackrel{\text {. }}{ }\end{array}$ & 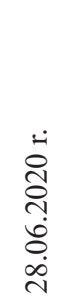 \\
\hline \multirow{2}{*}{ 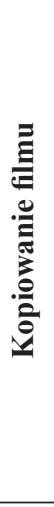 } & 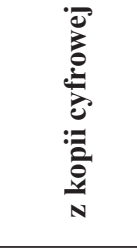 & 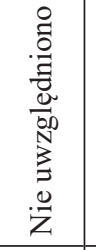 & 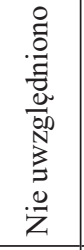 & 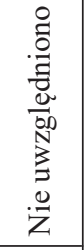 & 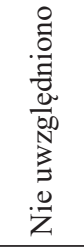 & 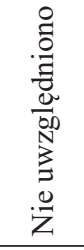 & 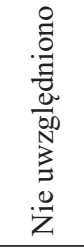 & 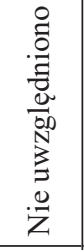 & 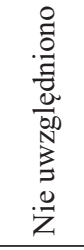 & 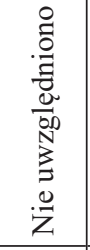 & 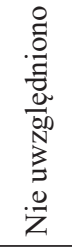 \\
\hline & 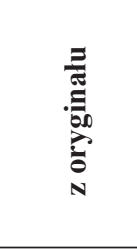 & 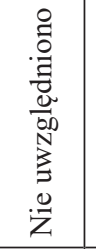 & 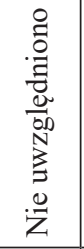 & 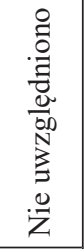 & 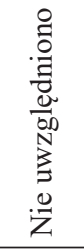 & 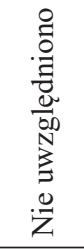 & 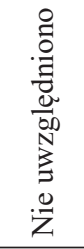 & 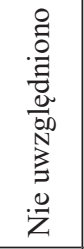 & 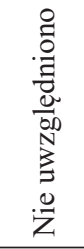 & 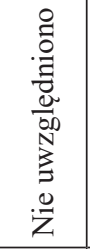 & 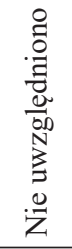 \\
\hline \multirow{2}{*}{ 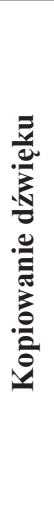 } & 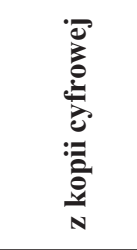 & 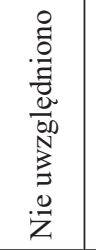 & 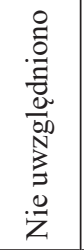 & 8 & 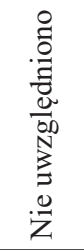 & 8 & 8 & 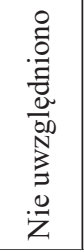 & 8 & 8 & $\begin{array}{l}00 \\
N \\
3 \\
0 \\
0 \\
z\end{array}$ \\
\hline & 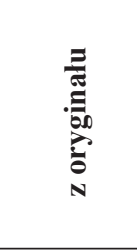 & 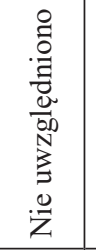 & 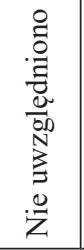 & $\begin{array}{l}8 \\
i\end{array}$ & 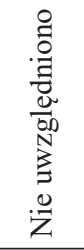 & $\begin{array}{l}8 \\
i\end{array}$ & 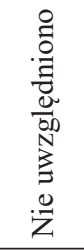 & 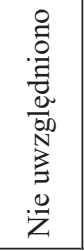 & $\begin{array}{l}8 \\
i\end{array}$ & $\begin{array}{l}8 \\
i\end{array}$ & 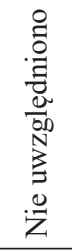 \\
\hline & 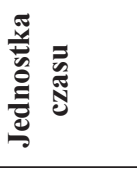 & 1 & 1 & 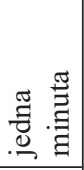 & 1 & 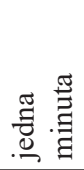 & 莺 㸓 & 1 & 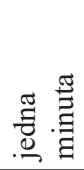 & 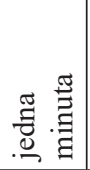 & 1 \\
\hline & 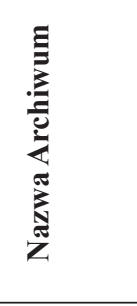 & 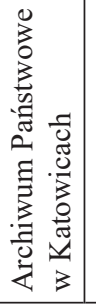 & 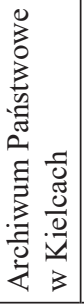 & 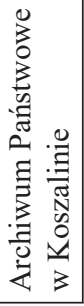 & 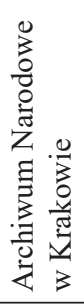 & 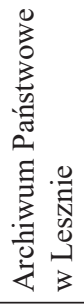 & 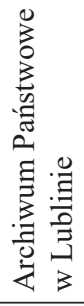 & 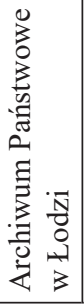 & 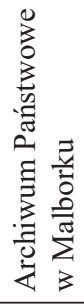 & 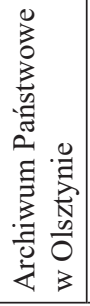 & 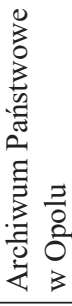 \\
\hline
\end{tabular}




\begin{tabular}{|c|c|c|c|c|c|c|c|c|c|c|c|}
\hline \multicolumn{2}{|c|}{ 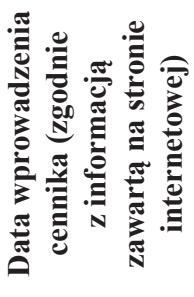 } & 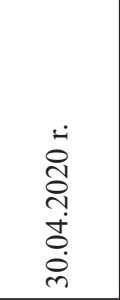 & $\begin{array}{l}\dot{0} \\
\text { ¿े } \\
\text { ஸे } \\
\stackrel{+}{0} \\
\dot{J}\end{array}$ & 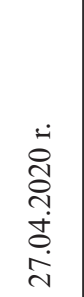 & 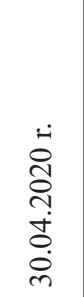 & 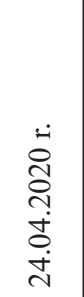 & 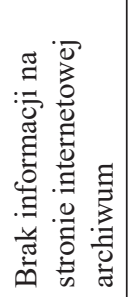 & 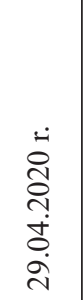 & 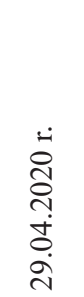 & 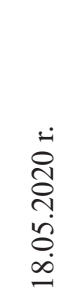 & 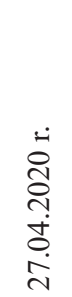 \\
\hline \multirow{2}{*}{ 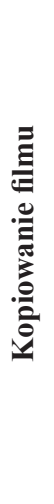 } & 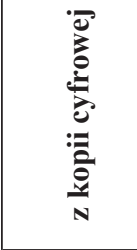 & 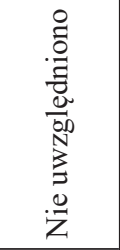 & 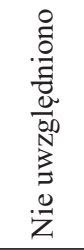 & 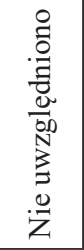 & 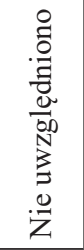 & 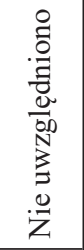 & 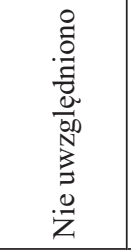 & 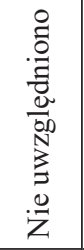 & 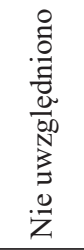 & 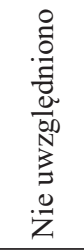 & 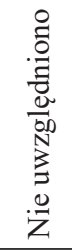 \\
\hline & 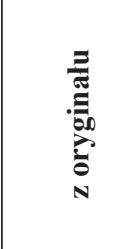 & 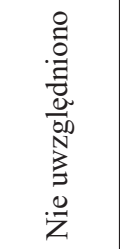 & 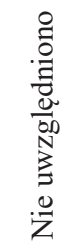 & 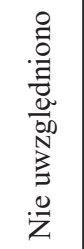 & 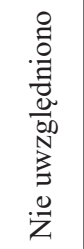 & 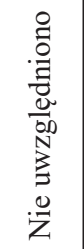 & 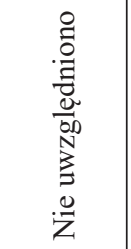 & 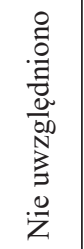 & 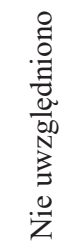 & 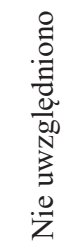 & 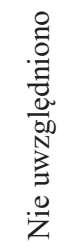 \\
\hline \multirow{2}{*}{ 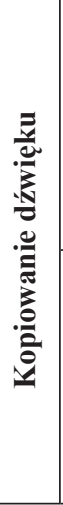 } & 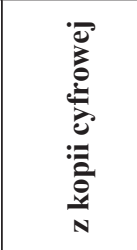 & $\begin{array}{l}8 \\
0\end{array}$ & $\begin{array}{l}8 \\
0\end{array}$ & $\begin{array}{l}8 \\
0\end{array}$ & 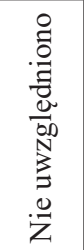 & $\begin{array}{l}8 \\
0\end{array}$ & $\begin{array}{l}8 \\
0\end{array}$ & $\begin{array}{l}8 \\
0\end{array}$ & $\begin{array}{l}8 \\
0\end{array}$ & $\begin{array}{l}8 \\
0\end{array}$ & 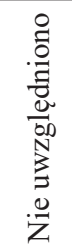 \\
\hline & 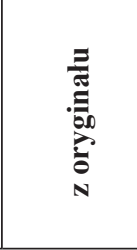 & $\begin{array}{l}8 \\
\text { in }\end{array}$ & $\begin{array}{l}8 \\
\text { in }\end{array}$ & $\begin{array}{l}8 \\
\text { in }\end{array}$ & 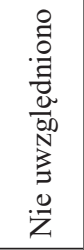 & $\begin{array}{l}8 \\
\text { in }\end{array}$ & $\begin{array}{l}8 \\
\text { in }\end{array}$ & $\begin{array}{l}8 \\
\text { in }\end{array}$ & $\begin{array}{l}8 \\
\text { in }\end{array}$ & $\begin{array}{l}8 \\
\text { in }\end{array}$ & 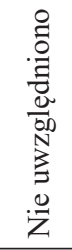 \\
\hline & 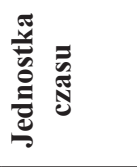 & 茎 䔅 & 莺 㸓 & 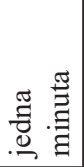 & 1 & 莺 莺 & 喼 & 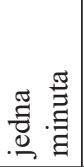 & 兽 恶 & 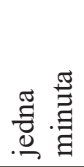 & 1 \\
\hline & 苞 & 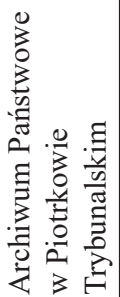 & 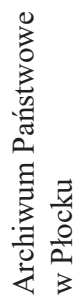 & 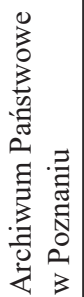 & 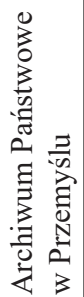 & 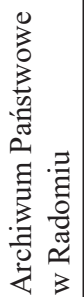 & 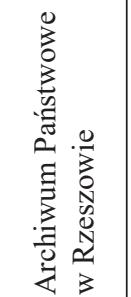 & 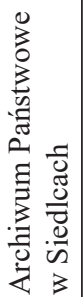 & 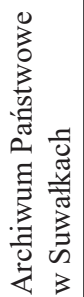 & 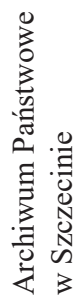 & 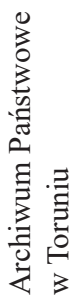 \\
\hline
\end{tabular}




\begin{tabular}{|c|c|c|c|c|c|c|}
\hline \multicolumn{2}{|c|}{ 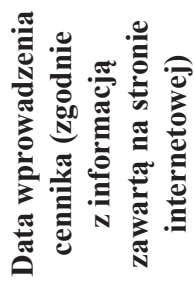 } & 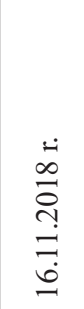 & 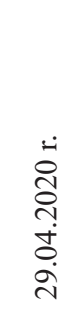 & 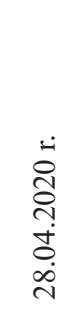 & $\begin{array}{l}\dot{0} \\
\stackrel{0}{0} \\
\text { + } \\
\dot{0} \\
\stackrel{0}{0}\end{array}$ & 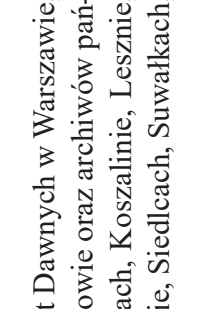 \\
\hline \multirow{2}{*}{ 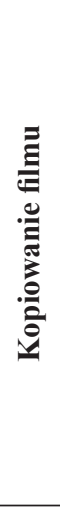 } & 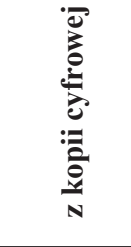 & 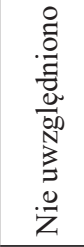 & 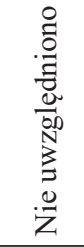 & 8 & 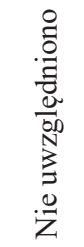 & 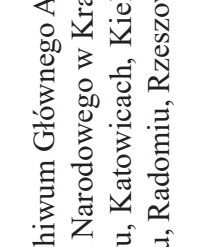 \\
\hline & 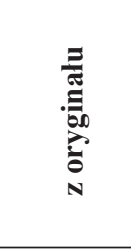 & 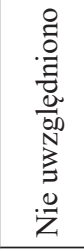 & 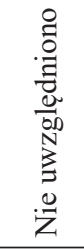 & 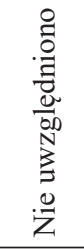 & 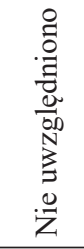 & 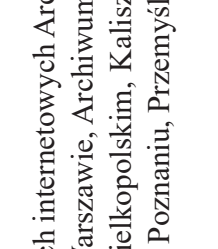 \\
\hline \multirow{2}{*}{ 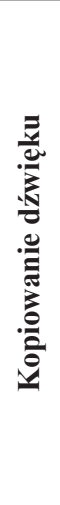 } & 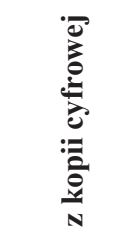 & 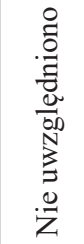 & 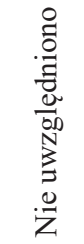 & $\begin{array}{l}8 \\
0\end{array}$ & $\begin{array}{l}8 \\
0\end{array}$ & 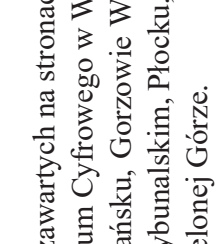 \\
\hline & 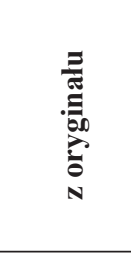 & 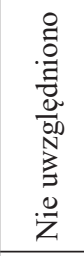 & 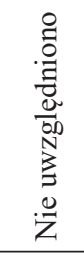 & 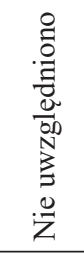 & $\begin{array}{l}8 \\
i n\end{array}$ & 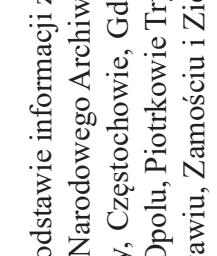 \\
\hline \multicolumn{2}{|c|}{ 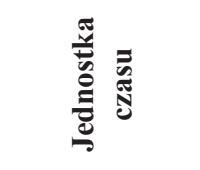 } & 1 & 1 & 1 & 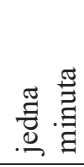 & 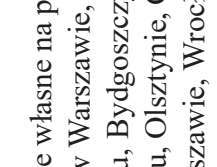 \\
\hline \multicolumn{2}{|r|}{ 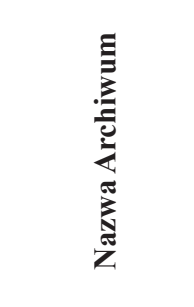 } & 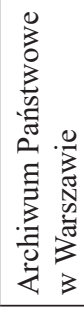 & 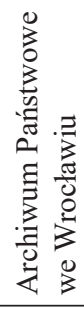 & 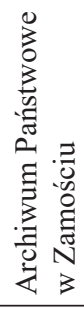 & 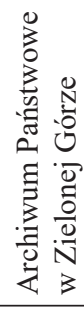 & 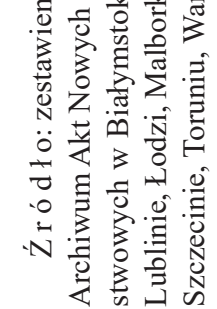 \\
\hline
\end{tabular}


Przechodząc do działań promocyjnych, realizacja tej grupy zadań jest szczególnie trudna $\mathrm{z}$ uwagi na konieczność pogodzenia funkcjonowania archiwów $\mathrm{W}$ zakresie stawianych celów promocyjnych $\mathrm{z}$ obowiązującymi przepisami prawnymi, jak i ze względu na realne możliwości każdego z archiwów, gdyby wziąć pod uwagę stan kadrowy oraz kompetencje i umiejętności. Jedynie kilka archiwów w Polsce traktuje materiał audiowizualny jako jeden z elementów promocyjnych na równi z pozostałymi grupami materiałów archiwalnych, przy czym udostępnianie przez Internet nagrań audio i wideo jest nadal w praktyce silnie ograniczone. Promocja zasobu, ze względu na prawne ograniczenia, musi uwzględniać dwa odrębne aspekty: $\mathrm{z}$ jednej więc strony mamy do czynienia z promocją audiowizualnego materiału archiwalnego przez Internet, z drugiej zaś ten sam Internet przyczynia się do radykalnego ograniczenia dostępu do materiałów przez potencjalnie większą liczbę zainteresowanych ${ }^{21}$. Stopień wykorzystania materiałów audiowizualnych $\mathrm{w}$ działalności promocyjnej w poszczególnych archiwach państwowych przedstawiono w tabeli 2.

Tabela 2. Rozmieszczenie materiału audiowizualnego na stronach archiwów państwowych według stanu na czerwiec $2020 \mathrm{r}$.

\begin{tabular}{|l|c|c|}
\hline \multirow{2}{*}{ Nazwa Archiwum } & \multicolumn{2}{c|}{$\begin{array}{c}\text { Umieszczenie na stronach internetowych materialu } \\
\text { dźwiękowego, filmowego lub dźwiękowo-filmowego }\end{array}$} \\
\cline { 2 - 4 } & $\begin{array}{c}\text { wlasnego lub we wspólpracy } \\
\text { z innym podmiotem }\end{array}$ & archiwalnego \\
\hline Archiwum Główne Akt Dawnych & Nie dotyczy & Nie dotyczy \\
\hline Archiwum Akt Nowych & - & - \\
\hline Narodowe Archiwum Cyfrowe & + & + \\
\hline Archiwum Państwowe w Białymstoku & - & - \\
\hline Archiwum Państwowe w Bydgoszczy & - & - \\
\hline $\begin{array}{l}\text { Archiwum Państwowe } \\
\text { w Częstochowie }\end{array}$ & - & - \\
\hline Archiwum Państwowe w Gdańsku & - & - \\
\hline Archiwum Państwowe w Gorzowie & - & - \\
\hline Archiwum Państwowe w Kaliszu & + & - \\
\hline Archiwum Państwowe w Katowicach & - & - \\
\hline Archiwum Państwowe w Kielcach & - & + \\
\hline Archiwum Państwowe w Koszalinie & + & - \\
\hline Archiwum Narodowe w Krakowie & - & - \\
\hline Archiwum Państwowe w Lesznie & - & - \\
\hline
\end{tabular}

${ }^{21}$ Zob. konkurs organizowany przez Archiwum Państwowe w Łodzi, w myśl którego zainteresowani oddają głosy na wybrane filmy dotyczące Łodzi i ziemi łódzkiej bez możliwości uprzedniego ich obejrzenia. 


\begin{tabular}{|c|c|c|}
\hline \multirow{2}{*}{ Nazwa Archiwum } & \multicolumn{2}{|c|}{$\begin{array}{l}\text { Umieszczenie na stronach internetowych materiału } \\
\text { dźwiękowego, filmowego lub dźwiękowo-filmowego }\end{array}$} \\
\hline & $\begin{array}{l}\text { własnego lub we współpracy } \\
\text { z innym podmiotem }\end{array}$ & archiwalnego \\
\hline Archiwum Państwowe w Lublinie & - & - \\
\hline Archiwum Państwowe w Łodzi & -* & - \\
\hline Archiwum Państwowe w Malborku & - & - \\
\hline Archiwum Państwowe w Olsztynie & + & - \\
\hline Archiwum Państwowe w Opolu & - & - \\
\hline $\begin{array}{l}\text { Archiwum Państwowe w Piotrkowie } \\
\text { Trybunalskim }\end{array}$ & - & - \\
\hline Archiwum Państwowe w Płocku & Brak danych & \\
\hline Archiwum Państwowe w Poznaniu & - & - \\
\hline Archiwum Państwowe w Przemyślu & + & - \\
\hline Archiwum Państwowe w Radomiu & -* & - \\
\hline Archiwum Państwowe w Rzeszowie & - & - \\
\hline Archiwum Państwowe w Siedlcach & - & - \\
\hline Archiwum Państwowe w Suwałkach & - & - \\
\hline Archiwum Państwowe w Szczecinie & - & - \\
\hline Archiwum Państwowe w Toruniu & - & - \\
\hline Archiwum Państwowe w Warszawie & - & - \\
\hline Archiwum Państwowe we Wrocławiu & - & - \\
\hline Archiwum Państwowe w Zamościu & - & - \\
\hline $\begin{array}{l}\text { Archiwum Państwowe w Zielonej } \\
\text { Górze }\end{array}$ & - & - \\
\hline
\end{tabular}

* na stronach internetowych archiwów w Łodzi i Radomiu znajdują się wypisy z inwentarzy zespołów archiwalnych zawierających nagrania dźwiękowe bez ich prezentacji.

Źródło: opracowanie własne na podstawie informacji zawartych na stronach internetowych Archiwum Głównego Akt Dawnych w Warszawie, Archiwum Akt Nowych w Warszawie, Narodowego Archiwum Cyfrowego w Warszawie, Archiwum Narodowego w Krakowie oraz archiwów państwowych w Białymstoku, Bydgoszczy, Częstochowie, Gdańsku, Gorzowie Wielkopolskim, Kaliszu, Katowicach, Kielcach, Koszalinie, Lesznie, Lublinie, Łodzi, Malborku, Olsztynie, Opolu, Piotrkowie Trybunalskim, Płocku, Poznaniu, Przemyślu, Radomiu, Rzeszowie, Siedlcach, Suwałkach, Szczecinie, Toruniu, Warszawie, Wrocławiu, Zamościu i Zielonej Górze.

Podsumowując, możliwości większego, niż dotąd udostępniania materiałów audiowizualnych przez archiwa państwowe muszą być oparte na dalszym, specyficznym prawnym uprzywilejowaniu archiwów. Osiągnięcie tego stanu jest wciąż utrudniane przez brak uzgodnień międzyresortowych (pomimo prób 
przynajmniej częściowego rozwiązania istotnych problemów związanych m.in. z opracowaniem i udostępnianiem materiałów audiowizualnych na szczeblu krajowym i międzynarodowym), które skutkują z jednej strony formalnym uprzywilejowaniem archiwów w przedmiocie prawa autorskiego i praw majątkowych, z drugiej zaś nie pozwalają na skuteczne wypełnienie zadań własnych archiwów w tej materii ${ }^{22}$. Trudno nie zgodzić się z Haliną Robótką, twierdzącą w 2007 r., iż prawo archiwalne wymaga rewizji i koniecznych zmian, ale nadal usłyszeć można więcej deklaracji, niż prześledzić te zmiany w praktyce ${ }^{23}$. Zmiany te, przeprowadzone w oparciu o szerokie konsultacje międzyresortowe i uwzględniające dotychczasowe światowe osiągnięcia techniczne i technologiczne, powinny objąć problematykę związaną $\mathrm{z}$ dokumentacją audiowizualną $\mathrm{w}$ archiwach państwowych, a przede wszystkim uwzględnić charakter zadań i specyfikę archiwów, o czym w praktyce legislacyjnej zapomina $\operatorname{się}^{24}$. Zadania te doskonale idą w parze ze zmianą postrzegania archiwów państwowych ${ }^{25}$ jako całości (na szczeblu ogólnopolskim), jak i każdego z nich z osobna (na szczeblu regionalnym), szczególnie w zakresie filozofii roli archiwów w społeczeństwie oraz roli materiału archiwalnego we wszystkich procesach społecznych, w których ów materiał występuje i których stał się fonicznym bądź audialnym odzwierciedleniem.

\section{Źródła}

Dyrektywa 2001/29/WE Parlamentu Europejskiego i Rady z dnia 22 maja 2001 r. w sprawie harmonizacji niektórych aspektów praw autorskich i pokrewnych w społeczeństwie informacyjnym (Dz. Urz. WE L 167/10).

Rozporządzenie Rady Ministrów z dnia 22 czerwca 2011 r. w sprawie sposobu i trybu udostępniania materiałów archiwalnych znajdujących się w archiwach wyodrębnionych wraz z załącznikiem do Rozporządzenia Rady Ministrów z dnia 22 czerwca 2011 r. w sprawie sposobu i trybu udostępniania materiałów archiwalnych znajdujących się w archiwach wyodrębnionych (Dz.U. 2011, nr 196, poz. 1161).

${ }^{22}$ A. Menne-Hartitz, Dostęp do archiwów, czyli przeformułowanie archiwalnego paradygmatu, „Archeion” 2002, t. 104, s. 68 i n.; W. Pęksa, Prawo archiwalne - wprowadzenie do zagadnienia, [w:] Prawo archiwalne. Stan aktualny i perspektywy zmian. Materiaty z międzynarodowej konferencji Toruń 20-21 kwietnia 2007 r., red. H. Robótka, Toruń 2007, s. 23; M. Konstankiewicz, Ksztaltowanie podstaw prawnych dziatalności archiwalnej w Polsce na przełomie XX i XXI w., „Archeion” 2019, t. 120 , s. 344 i n.

${ }^{23}$ H. Robótka, Kilka refleksji na temat polskiego prawa archiwalnego, [w:] Prawo archiwalne..., s. $31-39$.

${ }^{24}$ Zob. R. Golat, Prawo autorskie i prawa pokrewne..., s. 235-236.

${ }^{25}$ A. Rosa, O spotecznych rolach archiwów we wspótczesnym dyskursie archiwalnym w Polsce na marginesie dyskusji panelowej „Archiwa w przestrzeni publicznej”, „Archeion” 2019, t. 120, s. 155 in. 
Ustawa z dnia 14 lipca 1983 r. o narodowym zasobie archiwalnym i archiwach (t.j.: Dz.U. 2019, poz. $553,730,2020)$.

Ustawa z dnia 4 lutego 1994 r. o prawie autorskim i prawach pokrewnych (t.j: Dz.U. 2019, poz. 1231; Dz.U. 2020, poz. 288).

Zestawienie sumaryczne KN-1 działalność archiwalna według stanu na dzień 31 grudnia 2019 r., https://www.archiwa.gov.pl/files/zestawienie sumaryczne_KN-1_2019.pdf [dostęp: 26.11.2020].

Prawo autorskie i prasowe. 23. wydanie, stan prawny 14 września 2018 r., Warszawa 2018.

\section{Bibliografia}

Błaszczyk C., Propertarianistyczne teorie prawa autorskiego, Warszawa 2018.

Chojecka J., Archiwa otwarte. O obecności archiwów państwowych w przestrzeni publicznej w kontekście założeń, realizacji i efektów strategii archiwów państwowych na lata 2010-2020, „Archeion” 2019, t. 120, s. 122-135.

Golat R., Prawo autorskie i prawa pokrewne, Skrypty Becka, Warszawa 2016.

Howorka B., Prawo autorskie w pracy bibliotekarza, Nauka - Dydaktyka - Praktyka, Warszawa 2012.

Jabłońska M., Dokumentacja specjalna w archiwach. Opis tradycyjny i komputerowy, Toruń 2011. Jabłońska M., Nowe wyzwania archiwów. Komunikacja społeczna i public relations, Toruń 2016.

Konstankiewicz M., Kompetencje w zakresie prawnych aspektów ochrony własności intelektualnej $i$ dóbr osobistych w cyfrowym warsztacie archiwisty, [w:] Archiwistyka cyfrowa i nauki pomocnicze historii w edukacji archiwalnej. Problemy dydaktyki archiwistyki, Warszawa 2016, s. $34-40$.

Konstankiewicz M., Kształtowanie podstaw prawnych działalności archiwalnej w Polsce na przetomie XX i XXI w., „Archeion” 2019, t. 120, s. 337-366.

Kowalczyk M., Cyfrowe państwo. Uwarunkowania i perspektywy, Warszawa 2019.

Kubiczek B., Prace Międzynarodowego Zespotu Badawczego nad realizacja tematu. Opracowanie naukowych zasad oceny archiwalnej dokumentacji audiowizualnej (fotografii, nagrań i filmów), „Archeion” 1984, t. 77, s. 257-261.

Kurosz K., Artystyczne wykonanie utworu. Prawa osobiste i majątkowe aktorów, muzyków i innych wykonawców, Warszawa 2014.

Łosowski J., Archiwistyka jako dyscyplina pomocnicza historii, [w:] Nauki pomocnicze historii. Teoria, metody badań, dydaktyka, red. A. Jaworska i R. Jop, Warszawa 2013, s. 21-36.

Menne-Hartitz A., Dostęp do archiwów, czyli przeformułowanie archiwalnego paradygmatu, „Archeion" 2002, t. 104, s. 68-96.

Niewęgłowski A., Obrót materiałami archiwalnymi - zagadnienia wybrane, „Archeion” 2014, t. 115, s. $45-72$.

Paszkowski G., Nagrania dźwiękowe w archiwach, „Archeion” 1964, t. 41, s. 209-222.

Pęksa W., Prawo archiwalne - wprowadzenie do zagadnienia, [w:] Prawo archiwalne. Stan aktualny i perspektywy zmian. Materiały z międzynarodowej konferencji Toruń 20-21 kwietnia 2007 r., red. H. Robótka, Toruń 2007, s. 17-30. 
Robótka H., Kilka refleksji na temat polskiego prawa archiwalnego, [w:] Prawo archiwalne. Stan aktualny i perspektywy zmian. Materiały z międzynarodowej konferencji Toruń 20-21 kwietnia 2007 r., red. H. Robótka, Toruń 2007, s. 31-42.

Rosa A., O społecznych rolach archiwów we wspótczesnym dyskursie archiwalnym w Polsce na marginesie dyskusji panelowej „Archiwa w przestrzeni publicznej”, „Archeion” 2019, t. 120, s. $149-167$.

Targosz T., Włodarska-Dziurzyńska K., Umowy przenoszace autorskie prawa majątkowe, Warszawa 2010.

Wojciechowski R., Prawo autorskie, [w:] Prawo autorskie i własności przemysłowej. Wybrane zagadnienia, red. R. Wojciechowski, Siedlce 2014, s. 67-124.

Wojdon J., Internetowe zasoby archiwów w nauczaniu historii - marzenia i rzeczywistość, „Archeion" 2004, t. 107, s. 333-353.

Woźniak W., Misja Narodowego Archiwum Cyfrowego - spojrzenie w przyszłość, „Archeion” 2012, t. 113 , s. 87-100.

\section{Strony internetowe}

Zbiory Narodowego Archiwum Cyfrowego on-line, https://audiovis.nac.gov.pl/ [dostęp: 26.06.2020].

Strony internetowe: Archiwum Głównego Akt Dawnych w Warszawie, Archiwum Akt Nowych w Warszawie, Narodowego Archiwum Cyfrowego w Warszawie, Archiwum Narodowego w Krakowie oraz archiwów państwowych w Białymstoku, Bydgoszczy, Częstochowie, Gdańsku, Gorzowie Wielkopolskim, Kaliszu, Katowicach, Kielcach, Koszalinie, Lesznie, Lublinie, Łodzi, Malborku, Olsztynie, Opolu, Piotrkowie Trybunalskim, Płocku, Poznaniu, Przemyślu, Radomiu, Rzeszowie, Siedlcach, Suwałkach, Szczecinie, Toruniu, Warszawie, Wrocławiu, Zamościu i Zielonej Górze. 